\title{
Emissions halted of the potent greenhouse gas $\mathrm{SF}_{5} \mathrm{CF}_{3}$
}

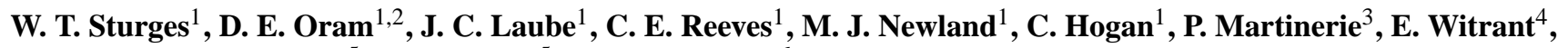 \\ C. A. M. Brenninkmeijer ${ }^{5}$, T. J. Schuck ${ }^{5}$, and P. J. Fraser ${ }^{6}$ \\ ${ }^{1}$ The School of Environmental Sciences, University of East Anglia, Norwich NR4 7TJ, UK \\ ${ }^{2}$ National Centre for Atmospheric Science, School of Environmental Sciences, Univ. of East Anglia, Norwich NR4 7TJ, UK \\ ${ }^{3}$ UJF - Grenoble 1/CNRS, Laboratoire de Glaciologie et Géophysique de l'Environnement (LGGE) UMR5183, Grenoble, \\ 38041, France \\ ${ }^{4}$ Grenoble Image Parole Signal Automatique (GIPSA-lab), Université Joseph Fourier/CNRS, BP 46, 38402 Saint Martin \\ d'Hères, France \\ ${ }^{5}$ Max Planck Institute for Chemistry, Air Chemistry Division, Mainz, Germany \\ ${ }^{6}$ Centre for Australian Weather and Climate Research, Commonwealth Scientific and Industrial Research Organisation, \\ Aspendale, Victoria 3195, Australia
}

Correspondence to: W. T. Sturges (w.sturges@uea.ac.uk)

Received: 22 December 2011 - Published in Atmos. Chem. Phys. Discuss.: 10 January 2012

Revised: 13 March 2012 - Accepted: 29 March 2012 - Published: 19 April 2012

\begin{abstract}
Long term measurements in background air (Cape Grim, Tasmania) and firn air (NEEM, Greenland) of the potent long-lived greenhouse gas $\mathrm{SF}_{5} \mathrm{CF}_{3}$ show that emissions declined after the late 1990s, having grown since the 1950s, and became indistinguishable from zero after 2003. The timing of this decline suggests that emissions of this gas may have been related to the production of certain fluorochemicals; production of which have been recently phased out. An earlier observation of closely correlated atmospheric abundances of $\mathrm{SF}_{5} \mathrm{CF}_{3}$ and $\mathrm{SF}_{6}$ are shown here to have likely been purely coincidental, as their respective trends diverged after 2002. Due to its long lifetime (ca. $900 \mathrm{yr}$ ), atmospheric concentrations of $\mathrm{SF}_{5} \mathrm{CF}_{3}$ have not declined, and it is now well mixed between hemispheres, as is also shown here from interhemispheric aircraft measurements. Total cumulative emissions of $\mathrm{SF}_{5} \mathrm{CF}_{3}$ amount to around $5 \mathrm{kT}$.
\end{abstract}

\section{Introduction}

In recent years the atmospheric growth of a number of fullyfluorinated and very long-lived greenhouse gases, with lifetimes on the order of a thousand years or more, has been observed; e.g. $\mathrm{CF}_{4}$ and $\mathrm{C}_{2} \mathrm{~F}_{6}$ (Worton et al., 2007), $\mathrm{C}_{3} \mathrm{~F}_{8}$ (Mühle et al., 2010), c- $\mathrm{C}_{4} \mathrm{~F}_{8}$ (Oram et al., 2012), $\mathrm{NF}_{3}$ (Weiss et al., 2008) and $\mathrm{SF}_{6}$ (Levin et al., 2010). These gases have exceptionally high Global Warming Potentials (GWPs), in some cases on the order of several thousand times that of $\mathrm{CO}_{2}$, and thus their unconstrained growth would be of considerable concern for the radiative forcing of climate.

In 2000 we reported our discovery of another, entirely unexpected, perfluorocarbon, namely $\mathrm{SF}_{5} \mathrm{CF}_{3}$ (Sturges et al., 2000). The term "super" greenhouse gases has been coined for this and other related and mainly sulfur-containing fluorocarbon gases (Gerstell et al., 2001). The presence of this gas was initially noticed as unidentified mass chromatographic peaks with $m / z$ ratios representative of $\mathrm{CF}_{3}^{+}$and $\mathrm{SF}_{5}^{+}$ ions during measurements of chlorofluorocarbons and $\mathrm{SF}_{6}$ in air samples from the middle stratosphere. The appearance of this substance in air samples from above $32 \mathrm{~km}$ altitude immediately implied that the "mystery" compound had to be long-lived. Two features marked this compound out as exceptional. Firstly, we determined that as a molecule it had the highest radiative forcing efficiency of any gas yet measured in the atmosphere $\left(0.57 \mathrm{~W} \mathrm{~m}^{-2} \mathrm{ppb}^{-1}\right)$. Secondly, it appeared to have grown in the atmosphere, between the mid-20th century and 1999, at almost exactly the same rate as $\mathrm{SF}_{6}$, to which it is closely chemically related. From this circumstantial evidence we concluded that its origins might be related to those of $\mathrm{SF}_{6}$, and we conjectured that it might be formed from high energy arc discharge in electrical equipment containing $\mathrm{SF}_{6}$ as a high voltage dielectric. 
Indeed there has since been some laboratory evidence for this (Huang et al., 2005; Solovev et al., 2007). Immediately following publication of our article, however, an open letter to the publishing journal from the company $3 \mathrm{M}$ stated that "one source of this compound is as a by-product of the manufacture of certain 3M fluorochemicals" (Santoro et al., 2000). It transpired that the relevant process was electrochemical fluorination for the production of perfluorooctanyl sulphonate, (PFOS) and other fluorosurfactants, used in the manufacture of foams and stain-resist coatings. They went on to note that these production operations were to be imminently curtailed in the USA. In a subsequent personal communication, their bottom-up emission estimates were evidently close to the global emission rate that we had deduced from observations.

We have updated the time series of atmospheric measurements from our original publication, and find that $\mathrm{SF}_{5} \mathrm{CF}_{3}$ has ceased to increase in the atmosphere, whereas the abundance of $\mathrm{SF}_{6}$ has continued to rise unabated. This clearly demonstrates that our original supposition that $\mathrm{SF}_{5} \mathrm{CF}_{3}$ originates from the degradation of $\mathrm{SF}_{6}$ was incorrect, and that all evidence now points to $3 \mathrm{M}$ being correct in their earlier assertion and that, as they predicted, emissions of this greenhouse gas have subsequently reduced to the point where they are no longer distinguishable by observation from zero.

\section{Methodology}

\subsection{Sampling and analysis}

The majority of the samples collected at Cape Grim, Tasmania $\left(40.4^{\circ} \mathrm{S}, 144.4^{\circ} \mathrm{E}\right)$ since 1994 were pumped directly into $3-\mathrm{dm}^{3}$ electrochemically passivated (Rasmussen) or Silcosteel-treated (Restek Corp.) stainless steel canisters at a pressure of ca. 2 atmospheres using a metal bellows air pump. Prior to 1994, the samples analysed were sub sampled from the parent Cape Grim air archive contained at high pressure (ca. 30 atmospheres) in large $\left(35 \mathrm{dm}^{3}\right)$ stainless steel vessels. In all cases the air samples were collected under baseline (clean marine air) conditions. Details of the Cape Grim air archive and sampling techniques have been reported elsewhere (Oram et al., 1995; Fraser et al., 1999). Analyses were carried out using gas chromatography separation followed by detection with an EBE configuration triplesector mass spectrometer (Waters/Micromass "Autospec"). Two slightly different techniques were employed using different capillary columns in the case of the Cape Grim air samples. In the first instance samples were preconcentrated on a glass bead trap cooled to $-185^{\circ} \mathrm{C}$ and separated on a Chrompack KCl-passivated alumina PLOT column. In the second case the samples were preconcentrated on a Hayesep D-packed trap cooled to $-78^{\circ} \mathrm{C}$. The two techniques are described in detail in Oram et al. (2012). Samples from NEEM and CARIBIC (see below) were exclusively analysed using the GasPro column. Analytical uncertainties were assessed from the reproducibility of duplicate samples and frequent calibration standard measurements.

To determine a corresponding trend of $\mathrm{SF}_{5} \mathrm{CF}_{3}$ in the Northern Hemisphere we also made measurements on air pumped from deep snow (firn) in northern Greenland (the North Greenland Eemian Ice Drilling project, NEEM; www. neem.nbi.ku.dk), which contains air dating from the early 20th century (Buizert et al., 2011). The sampling for trace gases at NEEM is described in Buizert et al. (2011) and Laube et al. (2010).

Finally, measurements were also made on 49 air samples collected from a Lufthansa aircraft during four flights at cruising altitudes of 8.6 to $12.2 \mathrm{~km}$ between Frankfurt, Germany and Cape Town/Johannesburg, South Africa in the period October 2009 to March 2011 in the framework of the CARIBIC project (Brenninkmeijer et al., 2007; www. caribic-atmospheric.com).

\subsection{2-D atmospheric modelling}

A 2-D global atmospheric chemistry-transport model was used to derive "top-down" emission estimates of $\mathrm{SF}_{5} \mathrm{CF}_{3}$ from the measurements made at Cape Grim. The model grid is divided into 24 equal area, longitudinally-averaged bands and has 12 vertical layers each of $2 \mathrm{~km}$ depth. The model has been described elsewhere (Hough 1989, 1991) and has been used to study the temporal behaviour and global distribution of other halocarbons (Fraser et al., 1999; Reeves et al., 2005; Laube et al., 2010; Oram et al., 2012). The latitudinal distribution of emissions is based on an even split between the two main production sites of PFOS by $3 \mathrm{M}$, Decatur, Alabama $\left(34^{\circ} \mathrm{N}, 87^{\circ} \mathrm{W}\right)$ and Antwerp, Belgium $\left(51^{\circ} \mathrm{N}, 4^{\circ} \mathrm{E}\right)$ (Paul et al., 2009). An atmospheric lifetime of $890 \mathrm{yr}$ was assumed for $\mathrm{SF}_{5} \mathrm{CF}_{3}$ (Montzka et al., 2011; Miller et al., 2002), and the annual emissions in the model were adjusted until the predicted concentrations matched the Cape Grim observations.

\subsection{Modelling trace gas transport in firn}

The relationship between past atmospheric trends and concentration profiles in firn can be established using models of trace gas transport in firn, which is dominated by diffusion but is also subject to gravitational fractionation, firn sinking and gas trapping effects. Here we use a direct model of transport in firn as described by Witrant et al. (2011), which includes the main modelling principles proposed by Rommelaere et al. (1997), Fabre et al. (2000) and Martinerie et al. (2009). We use a firn diffusivity profile for the conditions at NEEM that has been evaluated using nine reference gases: $\mathrm{CO}_{2}, \mathrm{CH}_{4}, \mathrm{SF}_{6}, \mathrm{HFC}-134 \mathrm{a}, \mathrm{CH}_{3} \mathrm{CCl}_{3},{ }^{14} \mathrm{CO}_{2}, \mathrm{CFC}-11$, CFC-12 and CFC-113 as described in Buizert et al. (2011). The diffusion coefficient for $\mathrm{SF}_{5} \mathrm{CF}_{3}$ was taken to be the same as that used in our earlier study (i.e. $0.0562 \mathrm{~cm}^{2} \mathrm{~s}^{-1}$, or 0.467 relative to that of $\mathrm{CO}_{2}$; Sturges et al., 2000). 


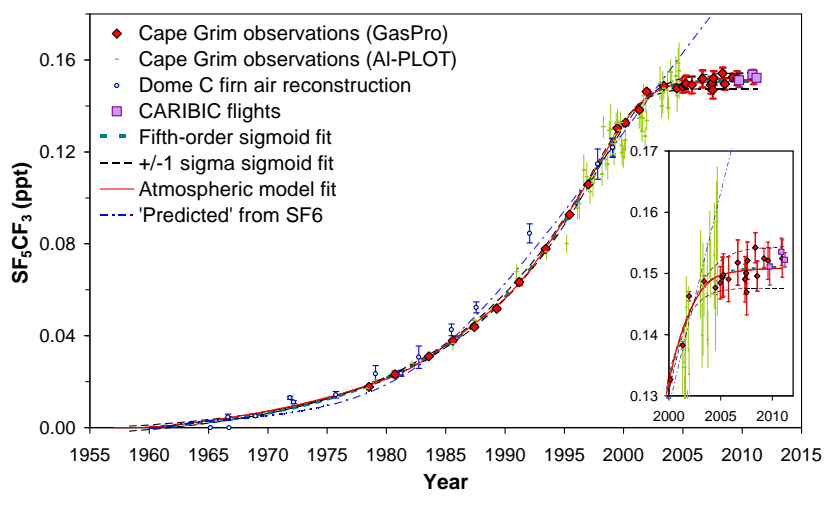

Fig. 1. The atmospheric record of $\mathrm{SF}_{5} \mathrm{CF}_{3}$ from measurements made in air collected at Cape Grim, Tasmania; in firn air collected at Dome Concordia, Antarctica; and in air collected between 8.6 and $12.2 \mathrm{~km}$ and $47^{\circ} \mathrm{N}-28^{\circ} \mathrm{S}$ from the CARIBIC aircraft. The dashed blue-green line is a least mean squares optimisation fit to a subset of the Cape Grim (see text) and Dome Concordia measurements (pre1978) with the uncertainty of the fit shown as black dashed lines. The red line (almost indistinguishable from the blue-green line) is the output mixing ratio from the atmospheric model run for the location of Cape Grim using the emissions shown in Fig. 2. The blue broken line shows the "predicted" $\mathrm{SF}_{5} \mathrm{CF}_{3}$ assuming a constant ratio to $\mathrm{SF}_{6}$ (see text). The inset figure is an expansion of the main graph between the dates 2000-2011.

\section{Results and discussion}

The Cape Grim measurements are compiled in Fig. 1 as red diamonds for the measurements made with the GasPro capillary column, and green dashes for those made with the Al-PLOT capillary column. There is excellent agreement between the two sets of analyses for the overlapping periods. The Al-PLOT measurements, however, had somewhat lower precision and were more scattered. The reason for this is not entirely clear (it might relate to slightly higher column bleed) as other gases showed generally excellent precision by the same method (e.g. Worton et al., 2007). Also shown, as blue circles, are the measurements from the original $\mathrm{SF}_{5} \mathrm{CF}_{3}$ paper. These were all from measurements in Antarctic firn air (Dome Concordia) and the dates have been estimated from co-measurements of $\mathrm{SF}_{6}$ as described in Sturges et al. (2000). The tabulated dates so determined can be found at the Carbon Dioxide Information Analysis Center (cdiac.ornl.gov/trends/otheratg/sturges/sturges.html). The Dome $\mathrm{C}$ measurements usefully extend the southern hemispheric trend to dates before that of first Cape Grim measurements. The final set of measurements shown in Fig. 1 (purple squares) are the means of the measurements from the flights of the CARIBIC aircraft in 2009, 2010 and 2011 in the upper troposphere and lower stratosphere. These agree very well with the last few years of $\mathrm{SF}_{5} \mathrm{CF}_{5}$ measurements at Cape Grim, which is discussed further below.
Due to the greater scatter of the Cape Grim Al-PLOT measurements, we have based our subsequent model and curve fitting on the Cape Grim GasPro measurements, but we have also included the Dome $\mathrm{C}$ measurements prior to 1978 to define the earlier part of the trend. A five-parameter sigmoid expression (SPSS, now Systat Software, SigmaPlot Version 7) has been used to fit a smoothed line to the points (dashed blue-green line), as this allows an envelope of uncertainty to be plotted based on the \pm 1 sigma deviation of the fit (dashed black lines). The 2-D atmospheric model output for the surface grid box for the latitude of Cape Grim is shown as a solid red line. This is barely distinguishable from the sigmoidal line fit, and falls entirely within the deviation of the latter, as can be better seen in the expanded panel (inset to Fig. 1). We therefore judge that the model fit represents well the observed trend.

The final curve plotted in Fig. 1, shown as a blue broken line, is a calculation of the $\mathrm{SF}_{5} \mathrm{CF}_{3}$ abundance expected had it exhibited the same relative molar abundance to $\mathrm{SF}_{6}$ as was assumed in the modelling study from our original paper, i.e. a ratio to $\mathrm{SF}_{6}$ of $3.05 \times 10^{-2}$. After 2002 it is clear that the apparent relationship between $\mathrm{SF}_{5} \mathrm{CF}_{3}$ and $\mathrm{SF}_{6}$ began to diverge, with the latter continuing to grow whilst the $\mathrm{SF}_{5} \mathrm{CF}_{3}$ abundance began to stabilise. It can, therefore, be concluded that the emission of $\mathrm{SF}_{5} \mathrm{CF}_{3}$ is not linked to that of $\mathrm{SF}_{6}$, contrary to our original hypothesis.

The measurements in Fig. 1 demonstrate the absence of significant emissions of $\mathrm{SF}_{5} \mathrm{CF}_{3}$ prior to the late 1960s, which is consistent with large-scale manufacture of PFOS having begun after $3 \mathrm{M}$ acquiring the patent for electrochemical fluorination in the 1950s. The first evidence for an unambiguous decrease in the atmospheric growth rate appears to have been around 2000, since which time the growth rate has declined rapidly. For the model to agree with the sigmoidal line fit, it was necessary to continue a small emission to the atmosphere after 2003 (see below). However, a model run (not shown) in which emissions were allowed to continue until 2003, and were then reduced to zero thereafter, resulted in a small decline in $\mathrm{SF}_{5} \mathrm{CF}_{3}$ (less than $1 \%$ or $0.001 \mathrm{ppt}$ ) between 2003 and 2011, but which still fell within the uncertainty of the measurements. Equally, a longer atmospheric lifetime would imply emissions closer to zero, as noted in a sensitivity test with a lifetime of $3000 \mathrm{yr}$ (not shown).

Rosiek et al. (2007) reported an upward trend in $\mathrm{SF}_{5} \mathrm{CF}_{3}$ (measured by gas chromatography with a modulated electron capture detector) between 2001 and 2003 in Krakow, Poland that is not consistent with the timing of the "turn over" in northern hemispheric abundances from this study. The 2D model used here, tuned to the Cape Grim record, suggests that growth in the Northern Hemisphere would have stopped after about 2001. Measurements by Busenberg and Plummer (2008) of the growth of $\mathrm{SF}_{5} \mathrm{CF}_{3}$ (also by electron capture detector) since the late 1980s from various sites in North America are in broad agreement with our measurements, and also suggest a possible turn over in concentrations 


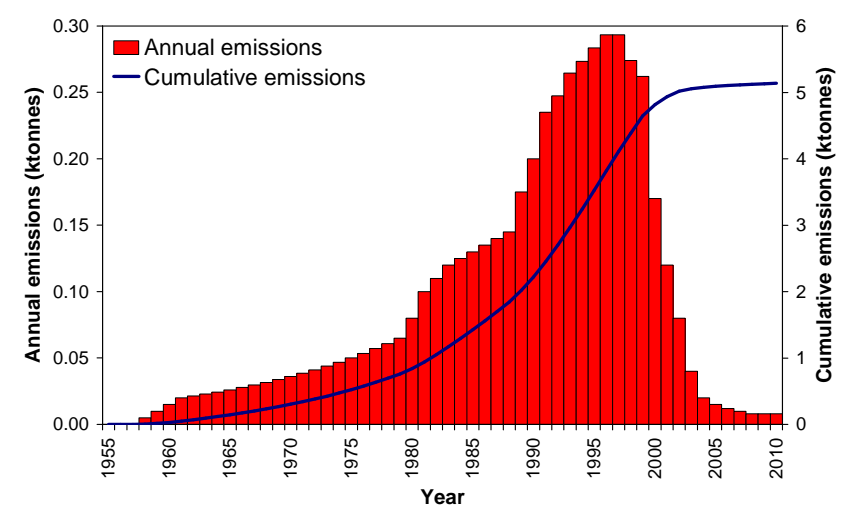

Fig. 2. The model-derived annual and cumulative emissions of $\mathrm{SF}_{5} \mathrm{CF}_{3}$ used to produce the atmospheric model fit scenario presented in Fig. 1 (the red line in Fig. 1).

since 2000, although it is difficult to be certain given the relatively large scatter in their reported measurements. It is not clear if analytical methodologies might have contributed to some of the discrepancies noted between these different studies.

The annual emissions used in the atmospheric model to reproduce the observed atmospheric abundance of $\mathrm{SF}_{5} \mathrm{CF}_{3}$ are shown in Fig. 2. Emissions rose year-on-year from the 1960s to the 1990s, peaking in 1996 and 1997 at around 300 tonnes $\mathrm{yr}^{-1}$, before progressively declining. The decline was very rapid from about 2000 to 2003 . As discussed above, we cannot confidently distinguish the emissions shown after 2003 (around 10 tonnes $\mathrm{yr}^{-1}$ ) from zero.

The same model run can also be used to produce a temporal trend for the latitude and elevation relevant to the Greenland firn air sampling site. This trend can then be used as input to the firn diffusion model to derive an expected depth profile for $\mathrm{SF}_{5} \mathrm{CF}_{3}$. This is shown in Fig. 3 (line) along with the actual measurements made in the firn air (symbols). There is very good agreement suggesting excellent compatibility between the two sets of measurements and further validation of the modelled atmospheric distribution of $\mathrm{SF}_{5} \mathrm{CF}_{3}$.

While atmospheric abundances were rising, e.g. during the 1990s, the model computes significant global latitudinal concentration gradients, and significant altitudinal gradients in the Northern Hemisphere. For example, for the year 1996 the model predicts $21 \%$ higher $\mathrm{SF}_{5} \mathrm{CF}_{3}$ mixing ratios in the Arctic than in the Antarctic. From about 2004 onwards, however, the model predicts no significant altitudinal or latitudinal gradient. The latter prediction is confirmed by the close similarity observed between the CARIBIC measurements in 2009, 2010 and 2011 in the upper troposphere/lower stratosphere, and the ground level measurements from NEEM (albeit at $3 \mathrm{~km}$ ) and those from Cape Grim (Fig. 1). Figure 4 further illustrates that, by the date of the aircraft flights, there was no evidence of a latitudinal gradient in $\mathrm{SF}_{5} \mathrm{CF}_{3}$, which also confirms the absence of further significant emissions to

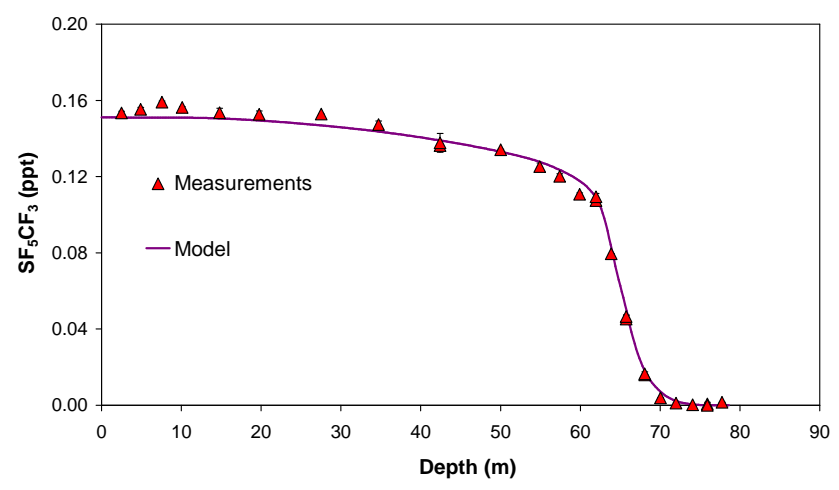

Fig. 3. The observed amounts (symbols) of $\mathrm{SF}_{5} \mathrm{CF}_{3}$ in samples collected at different depths of firn at the NEEM drilling site, Greenland. The purple line is the result of taking the long-term trend of the gas in the atmospheric model domain box appropriate for NEEM, based on the best fit to Cape Grim (red line in Fig. 1), and used as input to the firn diffusion model.

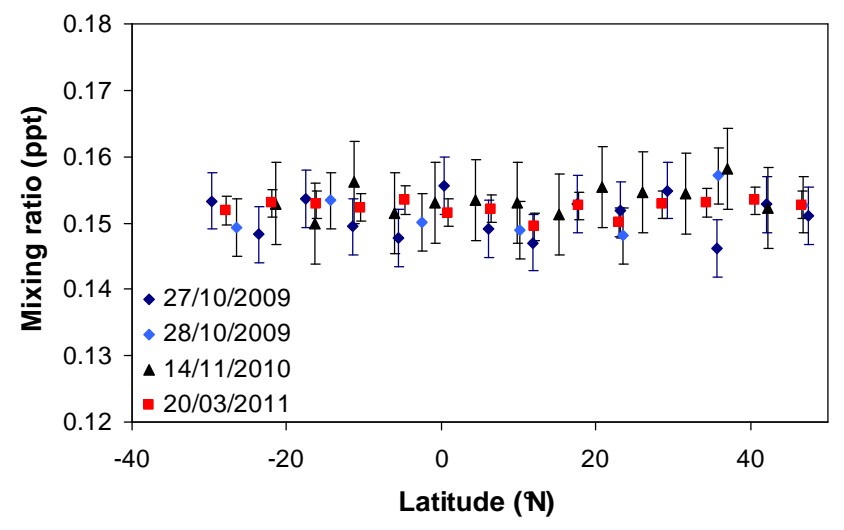

Fig. 4. Measurements of $\mathrm{SF}_{5} \mathrm{CF}_{3}$ from whole air samples collected from four interhemispheric CARIBIC flights flying at $8.6-12.2 \mathrm{~km}$, as a function of latitude.

the atmosphere, such that the mixing ratio of this gas had equilibrated throughout the global atmosphere.

$3 \mathrm{M}$ stated that a phase-out of PFOS manufacture was decided upon in 2000 (statement on "3M's Phase Out and New Technologies" at solutions.3m.com/wps/portal/3M/en_ US/PFOS/PFOA/Information/phase-out-technologies/), but also that overall greenhouse gas emissions (not just $\mathrm{SF}_{5} \mathrm{CF}_{3}$ ) had been reduced $40 \%$ since 1995 (Santoro, 2000). The PFOS phase-out was supposedly completed in 2002 (see "statement" above on 3M's web site). Our results confirm that there was indeed a rapid decline in emissions between 2000 and 2003, although the uncertainties in our observations preclude us from determining whether emissions actually ceased in 2003. Nevertheless, these findings strongly suggest that $\mathrm{SF}_{5} \mathrm{CF}_{3}$ emissions are indeed uniquely associated with such fluorochemical production. $3 \mathrm{M}$ state that associated fluorochemical production continued via a subsidiary (Dyneon), albeit using perfluorooctanoic 
acid (PFOA) not PFOS, but this too ceased in 2008 (see 3M "statement"). A number of companies worldwide continue to manufacture related perfluorocarboxylates (Rennner, 2006) but, it appears from our observations, without incurring substantial emissions of $\mathrm{SF}_{5} \mathrm{CF}_{3}$. $3 \mathrm{M}$ themselves have subsequently switched to processes that produce perfluorobutane sulfonate (PFBS) instead of the more toxic PFOS (3M "statement" and Renner, 2006).

\section{Conclusions}

The combined dataset from the Cape Grim atmospheric air archive, northern and southern hemispheric firn air, and interhemispheric aircraft flights results in a consistent atmospheric trend for $\mathrm{SF}_{5} \mathrm{CF}_{3}$ from the mid-20th century to 2011. Although the maximum atmospheric abundance of this molecule has never exceeded more than a small amount $(0.15 \mathrm{ppt})$, and thus currently contributes only minutely to climate forcing (Sturges et al., 2000), it (along with the other fully-fluorinated species referred to in the Introduction) represents an essentially irreversible change to the composition of the Earth's atmosphere and to the radiative forcing of the climate. The present cessation (or near-cessation), and presumed future avoidance of further emissions of this gas, is therefore to be welcomed.

\section{Supplementary material related to this article is available online at: http://www.atmos-chem-phys.net/12/ 3653/2012/acp-12-3653-2012-supplement.zip.}

Acknowledgements. WTS, DEO and JCL acknowledge the UK Natural Environment Research Council (NERC) for awards NE/F021194/1 (NEEM), R8/H12/38/012 (NCAS Composition) and NE/F015585/1 (NERC Fellowship) respectively. CH and MJN were both supported by NERC Doctoral Studentships. We thank Michael Leist and the staff of the Cape Grim Baseline Station and the CSIRO GASLAB for collection and maintenance of the Cape Grim air archive. The Cape Grim programme has previously received funding from the former UK Government Department of Environment (GA/4/2/57). The CARIBIC programme has previously received funding from UK NERC (NER/T/S/2000/01040 and GST/02/2218) and the European Union (EVK2-GT2001-00101). We are grateful to the entire CARIBIC team and all its partners. We are indebted to Jakob Schwander of the Physics Institute at the University of Berne, Switzerland for collecting the NEEM firn air samples. NEEM is directed and organized by the Center of Ice and Climate at the Niels Bohr Institute and US NSF, Office of Polar Programs. It is supported by funding agencies and institutions in Belgium (FNRS-CFB and FWO), Canada (GSC), China (CAS), Denmark (FIST), France (IPEV, CNRS/INSU, CEA and ANR), Germany (AWI), Iceland (RannIs), Japan (NIPR), Korea (KOPRI), The Netherlands (NWO/ALW), Sweden (VR), Switzerland (SNF), United Kingdom (NERC) and the USA (US NSF, Office of Polar Programs).

Edited by: T. Blunier

\section{References}

Brenninkmeijer, C. A. M., Crutzen, P., Boumard, F., Dauer, T., Dix, B., Ebinghaus, R., Filippi, D., Fischer, H., Franke, H., Frieß, U., Heintzenberg, J., Helleis, F., Hermann, M., Kock, H. H., Koeppel, C., Lelieveld, J., Leuenberger, M., Martinsson, B. G., Miemczyk, S., Moret, H. P., Nguyen, H. N., Nyfeler, P., Oram, D., O’Sullivan, D., Penkett, S., Platt, U., Pupek, M., Ramonet, M., Randa, B., Reichelt, M., Rhee, T. S., Rohwer, J., Rosenfeld, K., Scharffe, D., Schlager, H., Schumann, U., Slemr, F., Sprung, D., Stock, P., Thaler, R., Valentino, F., van Velthoven, P., Waibel, A., Wandel, A., Waschitschek, K., Wiedensohler, A., Xueref-Remy, I., Zahn, A., Zech, U., and Ziereis, H.: Civil Aircraft for the regular investigation of the atmosphere based on an instrumented container: The new CARIBIC system, Atmos. Chem. Phys., 7, 4953-4976, doi:10.5194/acp-7-4953-2007, 2007.

Buizert, C., Martinerie, P., Petrenko, V. V., Severinghaus, J. P., Trudinger, C. M., Witrant, E., Rosen, J. L., Orsi, A. J., Rubino, M., Etheridge, D. M., Steele, L. P., Hogan, C., Laube, J. C., Sturges, W. T., Levchenko, V. A., Smith, A. M., Levin, I., Conway, T. J., Dlugokencky, E. J., Lang, P. M., Kawamura, K., Jenk, T. M., White, J. W. C., Sowers, T., Schwander, J., and Blunier, T.: Gas transport in firn: multiple-tracer characterisation and model intercomparison for NEEM, Northern Greenland, Atmos. Chem. Phys. Discuss., 11, 15975-16021, doi:10.5194/acpd-11-159752011, 2011.

Busenberg, E. and Plummer, L. N.: Dating groundwater with trifluoromethyl sulfurpentafluoride $\left(\mathrm{SF}_{5} \mathrm{CF}_{3}\right)$, sulfur hexafluoride ( $\left.\mathrm{SF}_{6}\right), \mathrm{CF}_{3} \mathrm{Cl}$ (CFC-13), and $\mathrm{CF}_{2} \mathrm{Cl}_{2}$ (CFC-12), Water Resour. Res., 44, W02431, doi:10.1029/2007WR006150, 2008.

Fabre, A., Barnola, J.-M., Arnaud, L., and Chappellaz, J.: Determination of gas diffusivity in polar firn: Comparison between experimental measurements and inverse modelling, Geophys. Res. Lett., 27, 557-560, doi:10.1029/1999GL010780, 2000.

Fraser, P. J., Oram, D. E., Reeves, C. E., Penkett, S. A., and McCulloch, A.: Southern Hemispheric halon trends (1978-1998) and global halon emissions, J. Geophys. Res., 104, 1598515999, 1999.

Gerstell, M. F., Francisco, J. S., Yung, Y. L., Boxe, C., and Aaltonee, E. T.: Keeping Mars warm with new super greenhouse gases, P. Natl. Acad. Sci., 98, 2154-2157, doi:10.1073/pnas.051511598, 2001.

Hough, A. M.: The development of a two-dimensional global tropospheric model, 1, the model transport, Atmos. Environ., 23, 1235-1261, 1989.

Hough, A. M.: Development of a two-dimensional global tropospheric model: Model chemistry, J. Geophys. Res., 96, 73257362, 1991.

Huang, L., Zhu, L., Pan, X., Zhang, J., Ouyang, B., and Hou, H.: One potential source of the potent greenhouse gas $\mathrm{SF}_{5} \mathrm{CF}_{3}$ : The reaction of $\mathrm{SF}_{6}$ with fluorocarbon under discharge, Atmos. Environ., 39, 1641-653, doi:10.1016/j.atmosenv.2004.11.013, 2005.

Laube, J. C., Martinerie, P., Witrant, E., Blunier, T., Schwander, J., Brenninkmeijer, C. A. M., Schuck, T. J., Bolder, M., Röckmann, T., van der Veen, C., Bönisch, H., Engel, A., Mills, G. P., Newland, M. J., Oram, D. E., Reeves, C. E., and Sturges, W. T.: Accelerating growth of HFC-227ea (1,1,1,2,3,3,3-heptafluoropropane) in the atmosphere, Atmos. Chem. Phys., 10, 5903-5910, doi:10.5194/acp-10-5903-2010, 2010. 
Levin, I., Naegler, T., Heinz, R., Osusko, D., Cuevas, E., Engel, A., Ilmberger, J., Langenfelds, R. L., Neininger, B., Rohden, C. v., Steele, L. P., Weller, R., Worthy, D. E., and Zimov, S. A.: The global SF6 source inferred from long-term high precision atmospheric measurements and its comparison with emission inventories, Atmos. Chem. Phys., 10, 2655-2662, doi:10.5194/acp-102655-2010, 2010.

Martinerie, P., Nourtier-Mazauric, E., Barnola, J.-M., Sturges, W. T., Worton, D. R., Atlas, E., Gohar, L. K., Shine, K. P., and Brasseur, G. P.: Long-lived halocarbon trends and budgets from atmospheric chemistry modelling constrained with measurements in polar firn, Atmos. Chem. Phys., 9, 3911-3934, doi:10.5194/acp-9-3911-2009, 2009.

Miller, T. M., Arnold, S. T., Viggiano, A. A., and Knighton, W. B.: Electron attachment of $\mathrm{SF}_{5} \mathrm{CF}_{3}(296-563 \mathrm{~K})$ and calculations of the neutral and anion thermochemistry, J. Chem. Phys., 116, 6021-6027, doi:10.1063/1.1457442, 2002.

Montzka, S. A., Reimann, S. (Coordinating Lead Authors), Engel, A., Krüger, K., O’Doherty, S., Sturges, W., Blake, D., Dorf, M., Fraser, P., Froidevaux, L., Jucks, K., Kreher, K., Kurylo, M., Mellouki, A., Miller, J., Nielsen, O.-J., Orkin, V., Prinn, R., Rhew, R., Santee, M., Stohl, A., and Verdonik, D.: Scientific Assessment of Ozone Depletion: 2010, Global Ozone Research and Monitoring Project, Report No. 52, 516 pp., Chapter 1, Ozone-Depleting Substances (ODSs) and Related Chemicals, World Meteorological Organization, Geneva, Switzerland, 2011.

Mühle, J., Ganesan, A. L., Miller, B. R., Salameh, P. K., Harth, C. M., Greally, B. R., Rigby, M., Porter, L. W., Steele, L. P., Trudinger, C. M., Krummel, P. B., O’Doherty, S., Fraser, P. J., Simmonds, P. G., Prinn, R. G., and Weiss, R. F.: Perfluorocarbons in the global atmosphere: tetrafluoromethane, hexafluoroethane, and octafluoropropane, Atmos. Chem. Phys., 10, 5145-5164, doi:10.5194/acp-10-5145-2010, 2010.

Oram, D. E., Reeves, C. E., Fraser, P. J., and Penkett, S. A.: Measurements of HCFC-142b and HCFC-141b in the Cape Grim air archive: 1978-1993, Geophys. Res. Lett., 22, 2741-2744, doi:10.1029/95GL02849, 1995.

Oram, D. E., Mani, F. S., Laube, J. C., Newland, M. J., Reeves, C. E., Sturges, W. T., Penkett, S. A., Brenninkmeijer, C. A. M., Röckmann, T., and Fraser, P. J.: Long-term tropospheric trend of octafluorocyclobutane (c-C4F8 or PFC-318), Atmos. Chem. Phys., 12, 261-269, doi:10.5194/acp-12-261-2012, 2012.

Paul, A. G., Jones, K. C., and Sweetman, A. J.: A First Global Production, Emission and Environmental Inventory for Perfluorooctane Sulfonate, Environ. Sci. Technol., 43, 386-392, doi:10.1021/es802216n, 2009.
Reeves, C. E., Sturges, W. T., Sturrock, G. A., Preston, K., Oram, D. E., Schwander, J., Mulvaney, R., Barnola, J.-M., and Chappellaz, J.: Trends of halon gases in polar firn air: implications for their emission distributions, Atmos. Chem. Phys., 5, 2055-2064, doi:10.5194/acp-5-2055-2005, 2005.

Renner, R.: The long and the short of perfluorinated replacements, Environ, Sci. Technol., 40, 12-13, doi:10.1021/es062612a, 2006.

Rommelaere, V., Arnaud, L., and Barnola, J.: Reconstructing recent atmospheric trace gas concentrations from polar firn and bubbly ice data by inverse methods, J. Geophys. Res., 102, 3006930083, 1997.

Rosiek, J., Lasa, J., Sliwka, I., and Różański, K.: Application of GC and Modulated ECD for the Determination of $\mathrm{SF}_{5} \mathrm{CF}_{3}$ Mixing Ratios in the Atmosphere, Chem. Anal. (Warsaw), 52, 235-242, 2007.

Santoro, M. A.: Clarifying the $\mathrm{SF}_{5} \mathrm{CF}_{3}$ record, Science, 290, p. 935, 2000.

Solovev, S., Palmentieri, A., Potekhina, N. D., and Madey, T. E.: Mechanism for Electron-Induced $\mathrm{SF}_{5} \mathrm{CF}_{3}$ Formation in Condensed Molecular Films, J. Phys. Chem. C, 111, 18271-18278, 2007.

Sturges, W. T., Wallington, T. J., Hurley, M. D., Shine, K. P., Sihra, K., Engel, A., Oram, D. E., Penkett, S. A., Mulvaney, R., and Brenninkmeijer, C. A. M.: A Potent Greenhouse Gas Identified in the Atmosphere: $\mathrm{SF}_{5} \mathrm{CF}_{3}$, Science, 289, 611-613, doi:10.1126/science.289.5479.611, 2000.

Weiss, R. F., Mühle, J., Salameh, P. K., and Harth, C. M.: Nitrogen trifluoride in the global atmosphere, Geophys. Res. Lett., 35, L20821, doi:10.1029/2008GL035913, 2008.

Witrant, E., Martinerie, P., Hogan, C., Laube, J. C., Kawamura, K., Capron, E., Montzka, S. A., Dlugokencky, E. J., Etheridge, D., Blunier, T., and Sturges, W. T.: A new multi-gas constrained model of trace gas non-homogeneous transport in firn: evaluation and behavior at eleven polar sites, Atmos. Chem. Phys. Discuss., 11, 23029-23080, doi:10.5194/acpd-11-23029-2011, 2011.

Worton, D. R., Sturges, W. T., Gohar, L. K., Shine, K. P., Martinerie, P., Oram, D. E., Humphrey, S. P., Begley, P., Gunn, L., Barnola, J.-M., Schwander, J., and Mulvaney, R.: Atmospheric Trends and Radiative Forcings of $\mathrm{CF}_{4}$ and $\mathrm{C}_{2} \mathrm{~F}_{6}$ Inferred from Firn Air, Environ. Sci. Technol., 41, 2184-2189, doi:10.1021/es061710t, 2007. 